\title{
Dampak Privatisasi Air Bersih Perkotaan bagi Masyarakat Kaitannya dengan UU Sumber Daya Air
}

\section{Wijanto Hadipuro}

There are four stages of the organization of unban water supply systems. The debate on whether public or private sector that should manage urban water supply systems always happens at the fourth stage where there is a shift on local water to beh global money: where the global companies start to be involved in managing urban watersupply.

In Indonesia the debate started at the beginning of 1990 s when there were discussion on the necessity to change the law no. 11 issued in 1974 on imigation and it is still lasting until now, during the judicial review of the new waterlaw-lawno. 7 year 2004 on water.

Literature study on the impacts of inviting private sector to manage urban water supply shows that there are many problems arised: acces of the poor, tariff control and regulation, chemy-picking phenomenon, compution, environmental degradation, and the problem on the relationship with multi-lateral agencies such as the MF; the world Bank, and The Asian Development Bank

The law No. 7 year 2004 on water which is proved to give some privileges for private sector to be involved in managing urban water systems is not sufficient to guarantee that the problems arised in involving private sector could be solved.

Kata Kunci: Dampak, Investasi, Lingkungan,Privatisasi,Perkotaan, Regulasi, Sumberdaya Air

$\mathrm{M}$ ayoritas kajian yang bersifat internasional menunjukkan bahwa organisasi sistem penyediaan air bersih perkotaan secara garis besar dapat dibagi ke dalam empat tahapan. ${ }^{1}$ Tahap pertama yang berlangsung sampai paruh kedua abad 19 adalah tahap dimana sistem penyediaan air bersih perkotaan dilakukan oleh perusahaan-perusahaan swasta yang relatif kecil yang hanya memasok air bersih hanya pada sebagian dari daerah perkotaan (biasanya daerah-daerah alit).

Periode kedua adalah periode munisipalisasi. Periode ini muncul akibat adanya keprihatinan terhadap kondisi lingkungan yang memburuk dan munculnya kebutuhan sanitasi perkotaan. Pada tahap ini terjadi konsolidasi penyediaan air bersih sehingga standar layanannya mencakup seluruh daerah perkotaan dan terintegrasi dengan sistem pembuangan limba cair. Motivasiuntuk memperoleh keuntungan bukan menjadi tujuan utama pada periode ini.

Periode ketiga dimulai kira-kira setelah berakhirnya Perang Dunia I. Saat itu sektor air dan juga listrik serta telekomunikasi

' Penjelasan lengkap tentang rujukan studi untuk pembagian pentahapan dan rujukan detil studi untuk tiap tahapan bisa dilihat dalam artikel Erik Swyngedouw. 2003. Privatising $\mathrm{H} 2 \mathrm{O}$ Turning Local Waters into Global Money dalam Journal fur Entwicklungspolitik, Vol. XIX, 2003 (4) hal. 10-33. 
menjadi perhatian nasional. Pemerintah pusat dengan berbagai kadar mulai terlibat dalam melakukan kontrol, regulasi, dan investasi dan mulai berperan lebih besar dalam penyediaan sarana layanan publik ini.

Awal resesi global tahun 1970-an dimulai periode baru yang oleh Swyngedowu (2003) dijadikan judul makalah yaitu periode air lokal menjadi uang global. Sektor publik dan privat mulai saling berinteraksi dalam sektor air. Tekanan anggaran dan tekanan bertambahnya jumlah penduduk perkotaan yang harus dilayani memaksa sektor publik untuk mulai melibatkan sektor swasta besar berskala global dalam pengelolaan air bersih dan sanitasi perkotaan.

Komodifikasi, privatisasi dan komersialisasi menjadi penanda dimulainya tahap keempat ini. Perdebatan tentang apakah sektor publik atau sektor privat yang sebaiknya mengelola air bersih perkotaan juga terjadi pada tahap ini. ${ }^{2}$

Saat terjadinya perubahan ke tahap keempat ini dan terjadinya perdebatan berbeda antara satu negara dengan negara lainnya. Di Indonesia perdebatan tentang apakah sektor publik atau privat yang sebaiknya mengelola air bersih perkotaan mulai terjadi sejak munculnya wacana kebutuhan akan penggantian UU No. 11 tahun 1974 tentang Pengairan yang kemudian bermuara pada disyahkannya UU No. 7 tahun 2004 tentang Sumber DayaAir. ${ }^{3}$

\section{Privatisasi, Komodifikasi dan Komersialisasi}

Istilah privatisasi sering diinterpretasikan secara sempit terutama jika berkaitan dengan kepentingan ekonomi politik. ${ }^{4}$ Padahal privatisasi sifatnya sangat luas, mulai dari transfer operasi sampai transfer kepemilikan dari negara kepada perubahaan swasta. ${ }^{5}$ Basri (2003) menjelaskan dengan detil cakupan privatisasi mulai dari yang paling lunak yaitu contracting out (outsourcing) sampai yang paling ekstrim yaitu penjualan aset. ${ }^{6}$ Lebih jauh Basri mendefinisikan privatisasi

2 Perdebatan tentang sektor publik dan privat dalam pengelolaan air bersih perkotaan sebenarnya mereduksi fakta bahwa ada model lain yaitu penyediaan air bersih membasiskan masyarakat. Refernsi tentang hal ini bisa dilihat misalnya pada artikel Alphonce G. Kyessi. 2005. Community-based Urban Water Management in Fringe Neighbourhoods: the Case of Dar es salam, Tanzania dalam Habitat International Vol. 29 Issue 1 Maret 2005 hal. 1-25. Karen J. Bakker 2003. From Public to Private to Mutual? Restructuring Water Supply Governance in england and Wales mengutip McGRanaham et.al (2001) mempergunakan istilah 'command', 'commercial' dan 'collective' masingmasing untuk publik, privat dan model berbasiskan masyarakat. Model ini bahkan menjadi model 'baru' di Inggris dan Wales setelah model privatisasi dilewati.

${ }^{3}$ Detil kronologis tentang hal ini bisa dilihat dalam Komersialisasi dan Privatisasi Sektor Air Indonesia: Studi Atas WATSAL dan RUU Sumber Daya Air yang disusun oleh indonesian Forum on Globalization Solo.

4 Istilah privatisasi yang dipergunakan sebagai argumen pemerintah Indonesia dalam berbagai diskusi tentang sumber daya air hanya mengacu pada pengertian privatisasi sebagai penjualan saham atau aset pemerintah kepada pihak lain. UU No. 19 tahun 2003 tentang Badan Usaha Milik Negara bab I Ketentuan Umum Pasal 1 poin 12 juga mengartikan privatisasi hanya sebagai penjualan saham.

${ }^{5}$ Lihat Peter H. Gleick (et. Al). 2002. The World's Water The Biennial Report on Freshwater Resources 2002-2003. Washington: Island Press, hal. 35.

' Menurut Faisal Basri urutan cakupan privatisasi adalah mulai contracting out (outscorcing), public-private competition, franchise, vouchers, internal markets, commercialization, volunteers acitivities, management 
sebagai segala langkah atau tindakan yang mengurangi atau menurunkan kepemilikan negara dan atau keterlibatan langsung negara di dalam manajemen perusahaan.

Diskusi tentang privatisasi air bersih perkotaan memang sering dibedakan menjadi dua sesuai dengan dua model privatisasi yang dikenal di dunia untuk sektor air perkotaan. Inggris dan Wales merupakan model privatisasi pertama yang ditandaj dengan kepemilikan penuh perusahaan penyedia air bersih dan sanitasi perkotaan oleh swasta. Sementara privatisasi model Perancis berbeda dengan model lnggris. Dalam model privatisasi Perancis, kepemilikan infrastruktur masih berada di tangan pemerintah daerah (municipalities) masingmasing. Pemerintah daerah kemudian mentenderkan jasa pelayanan ${ }^{7}$ kepada perusahaan swasta untuk kontrak yang bersifat jangka panjang.

Istilah komidifikasi dan komersialisasi sebenarnya memilik arti yang tidak jauh berbeda. Gleick et. al (2002) mendefinisikan komodifikasi sebagai proses mengubah barang atau jasa yang semula pengelolaannya mengikuti nonmarket social rules menjadi mengikuti aturan pasar. Model pengelolaan berbasis komunitas di pedesaan baik untuk irigasi maupun air bersih merupakan contoh pengelolaan air yang mengikuti nonmarket social rules. Sementara air minum dalam kemasan adalah contoh air yang sudah menjadi komoditi yang mengikuti aturan pasar.

Komersialisasi menurut Bekker (2003b) mengacu pada penataan ulang aturan, norma, dan kebiasaan institusi pengelola, dengan penggunaan mekanisme pasar, teknik pengambilan keputusan yang mengacu pada pasar, dan pergantian prinsip Kynesian-welfais $t^{8}$ menjadi prinsip neo-liberal ${ }^{9}$ dalam pengambilan keputusan. Menurut Bekker, komersialisasi tidak selalu harus terjadi melalui privatisasi. Beberapa perusahaan penyedia air bersih perkotaan yang dimiliki sektor seperti di Amsterdam misalnya, dikelola menurut kaidah-kaidah komersialisasi. Di Indonesia anggapan bahwa Perusahaan Daerah Air Minum (PDAM) harus menyumbang pada

contracts, corporazation, most efficient organizations, performance-based organization, activity-based costing, self-help (transfer to non profit organization), employee stock ownership, joint ventures, public-private-partnership, user fees, long-term lease, private infrastructure development and operation (Build, Operate and Transfer/BOT, Build, Own and Operate, dan sejenisnya), divesture, sampai penjualan aset. Karen J. Bakker dalam makalahnya Archipelagos and Networks: Urbanization and Water Privatization in the South menjelaskan jenis kontrak yang biasa dilakukan dalam penyediaan ait bersih yang melibatkan sektor swasta: service contract, managemen contract, lease, BOO/BOT, concessio, divesture. Jenis beserta alokasi tanggung jawabnya juga bisa dilihat dalam artikel Bakker.

${ }^{7}$ Model privatisasi Perancis ini kemudian banyak disebut sebagai Public Private Partnership atau Private Sector Participation. Jenis-jenis partnership diantarnaya meliputi konsesi, OBT, affermage contract atau leasing, operation and maintenance, dan management support. Detilnya bisal dilihat dalam Public Privatte partnership in Management of Water Service di-download tanggal 3 Januari 2003 dari http://www.suez.com/documents/ english/gestion-uk.pdf yang merupakan prospektus perusahaan Suez Ondeo.

' Sebuah prinsip yang percaya pada campur tangan pemerintah demi kesejahteraan masyarakat.

9 Prinsip neo-liberal yang dimaksud dapat dilihat dalam buku Bonnie Setiawan. 2000. Stop WTO, hal 6-7: the tule of market, memotong pengeluaran publik untuk pelayanan sosial, deregulasi, privatisasi, dan menghapus konsep barang publik dan menggantinya dengan tanggung jawab individual. 
pendapatan Asli Daerah (PAD) ${ }^{10}$ yang berarti harus memperoleh keuntugnan dan keuntungannya dipergunakan untuk pembiayaan sektor lain juga bisa dimasukkan ke dalam kategori komersialisasi air meskipun dikelola dan dimiliki oleh publik.

\section{Privatisasi dalam UU No. 7 Tahun 2004}

Di dalam UU No. 7 tahun 2004 tentang sumber daya air tidak ada satu katapun tentang privatisasi, seperti yang berulang kali dinyatakan baik pihak pemerintah maupun DPR. ${ }^{11}$ Kenyataannya dalam pasal 40 ayat 4 dinyatakan:

Koperasi, Badan Usaha Swasta (cetak tebal dari penulis), dan masyarakat dapat berperan serta dalam penyelenggaraan pengembangan sistem penyediaan air minum.

\section{Penjelasan pasal:}

Dalam hal di suatu wilayah tidak terdapat penyelenggaraan air minum yang dilakukan oleh badan usaha milik negara dan latau badan usaha milik daerah, penyelenggaraan air minum di wilayah tersebut dilakukan oleh koperasi, badan usaha swasta (cetak tebal dari penulis) dan masyarakat.

Jelas bahwa badan usaha swasta dapat terlibat dalam penyelenggaraan air minum termasuk di perkotaan. Meskipun tidak begitu jelas model keterlibatan badan usaha swasta yang dimaksud apakah mempergunakan model keterlibatan partnership Perancis ataukah model kepemilikan penuh perusahaan penyedia air minum Inggris dan Wales. Ketidakjelasan bisa diartikan bahwa keduanya bisa dilaksanakan di Indonesia.
Berikut beberapa pasal yang berkaitan dengan keterlibatan badan usaha swasta dalam penyediaan air minum.

Berkaitan dengan harga air minum, efisiensi, cakupan layanan, dan integrasi penyediaan air minum dan sanitas pemerintah

to Beberapa contoh pandangan anggota legislatif, eksekutif termasuk manajemen PDAM tentang 'kewajiban' PDAM menyumbang PAD dapat dilihat pada artikel Wijanto Hadipuro. 2003. PDAM dalam Era Desentralisasi Fiskal dalam Renai Jurnal Politik Lokal \& Sosial - Humaniora Tahun III, No. 2 Edisi Musim Mareng, April-Mei 2003. Peraturan Daerah yang melandasi pendirian PDAM menyatakan alokasi laba banyak yang tidak terkait dengan perbaikan kinerja secara langsung untuk pelayanan air kepada masyarakat. Sebagai contoh PDAM Kota Semarang sesuai dengan Perda No. 7 Tahun 1978 tentang Pendirian PDAM disebutkan alokasi laba yang diperoleh dari pendapatan PDAM 80\%-nya dipergunakan untuk kepentingan pemenuhan pembiayaan daerah, pensiun, sosial, dan lain-lain. Lihat laporan lengkap penelitian Yayasan Geni, Gita Pertiwi, Program Magister Lingkungan dan Perkotaan Unika Soegijapranata, dan INFID. 2004. Kinerja PDAM di Jawa Tengah - Studi Kritis Antisipasi Privatisasi.

11 Meskipun sering ada kontradiksi pernyataan apakah ada maksud privatisasi atau tidak dalam UU tersebut. Kata privatisasi memang tidak ada, tetapi ada pernyataan yang menyangkal maksud terselubung privatisasi air bersih perkotaan dalam UU tersebut seperti makalah Pelurusan Opini Publik terkait dengan RUU Sumber Daya Air yang dipresentasikan oleh Siswoko dalam Diskusi 'Bedah RUU Sumber Daya Air' Indonesian Forum on Globatization dan Harian Kompas Semarang tanggal 7 Oktober 2003; dan ada pula yang secara tidak langsung menyatakan ada unsur privatisasi di dalamnya, misalnya dalam Keterangan Tertulis Pemerintah atas Permohonan hak Uji Undang-undang Republik indonesia No 7 tahun 2004 tentang Sumber Daya Air terhadap undang-undang Dasar Republik Indonesia tahun 1945 tanggal 
dapat membentuk badan ${ }^{12}$ yang dapat dilihat pada pasal 40 ayat 7 yang berbunyi:

Untuk mencapai tujuan pengaturan pengembangan sistem penyediaan air minum dan sanitasi sebagaimana dimaksud pada ayat (5) dan ayat (6), pemerintah dapat membentuk badan yang berada di bawah dan bertanggung jawab kepada menteri (cetak tebal dari penulis) yang membidangi sumber daya air.

\section{Ayat 5 yang dimaksud berbunyi:}

Pengaturan terahdap pengembangan sistem penyediaan air minum bertujuan untuk:

a. Terciptanya pengelolaan dan pelayanan air minum yang berkualitas dengan harga yang terjangkau;

b. Tercapainya kepentingan yang seimbang (cetak tebal dari penulis) antara konsumen dan penydia jasa pelayana, dan

c. Meningkatnya efisiensi dan cakupan pelayanan air minum.

Selain penyediaan air minum, badan usaha swasta juga dapat berperan dalam berbagai bentuk pengusahaan air pada sebagian wilayah sungai. Tidak ada spesifikasi khususnya untuk penjelasan pasal 45 ayat 4 huruf a: penggunaan air pada suatu lokasi tertentu. Interpretasi bisa dilakukan, misalnya untuk air minum dalam kemasan atau usaha sejenisnya, barangkali: karena untuk instalasi pengolahan air bersih (water treatment plant) atau reservoir sebenarnya sudah dinyatakan dalam pasal 40 ayat 4 karena sudah termasuk dalam sistem penyediaan air minum. ${ }^{13}$

Jika pada penyediaan air minum tidak jelas model yang akan dipergunakan, maka model pelibatan swasta untuk jenis usaha yang diatur pada pasal 45 ini jelas dinyatakan pada penjelasan pasal 45 ayat 3 .
Badan usaha swasta bisa dilibatkan melalui partnership. Tidak jelas apakah yang dimaksud 'dan sebagainya' pada Penjelasan Pasal 45 ayat 3 . apakah juga berarti kepemilikan penuh, meskipun seharusnyya tidak. Berikut kutipan pasal dan ayat-nya.

\section{Pasal 45 ayat 3}

Pengusahaan sumber daya air selain sebagaimana dimaksud pada ayat (2) dapat dilakukan oleh perseorangan, badan usaha, atau kerja sama antar badan usaha (cetak tebal dari penulis) berdasar izin pengusahaan dari Pemerintah atau pemerintah daerah sesuai dengan kewenangannya.

28 Januari 2005 hal. 45: "Bahwa setelah menjadi rumusan dalam pasal 40 ayat (4) kemudian diartikan lain, yaitu bahwa pasal ini akan mendorong privatisasi, undang-undang telah juga mengantisipasi dan memberikan rambu-rambu yang ketat. Untuk mengendalikan privatisasi ...'

${ }^{12}$ Rancangan Peraturan Pemerintah tentang Pengembangan Sistem Penyediaan Air Minum yang disusun oleh Direktorat Jendral Tata Perkotaan dan Tata Perdesaan Departemen Pekerjaan Umum menyatakan bahwa badan yang diberntuk adalah Badan Air Minum dan Sanitasi. Lihat Bab VIl. Namun tugasnya tidak sampai mengatur tarif. Tugasnya hanya memberikan izin; melaksanakan pemantauan, evaluasi, dan pelaporan; memfasilitasi penyelesaian sengketa; dan melaksanakan koordinasi. Tarif diputuskan pada Badan Musyawarah yang tidak jelas apa yang dimaksud dan siapa anggota Badan Musyawarah tersebut.

${ }^{13}$ Lihat. Ibid. Pasal 6 ayat 1 'Sistem Penyediaan air minum jaringan perpipaan meliputi unit air baku, unit produksi, unit distribusi dan unit pelayanan. (cetak tebal dari penulis)'. Bisa dibayangkan jika saja badan usaha swasta hanya beroperasi pada unit air baku saja karena boleh menguasai sumber air dari sebagian wilayah sungai. 


\section{Penjelasan pasal 45 ayat 3:}

Yang dimaksud dengan badan usaha pada ayat ini dapat berupa badan usaha milik negara/ badan usaha milik daerah (yang bukan badanusaha pengelola sumber daya air wilayah sungai), badan usaha swasta (cetak tebal dari penulis), dan koperasi.

Kerja sama dapat dilakukan, baik dalam pembiayaan investasi pembangunan prasarana sumber daya air maupun dalam penyediaan jasa pelayanan dan/atau pengoperasian prasarana sumber daya air. Kerja sama dapat dilaksanakan dengan berbagai cara misalnya dengan pola bangun guna serah (bulid, operate, and transfer), perusahaan patungan, kontrak pelayanan, kontrak manajemen, kontrak konsesi, kontrak sewa dan sebagainya. Pelaksanaan berbagai bentuk kerja sama yang dimaksud harus tetap dalam batas-batas yang memungkinkan pemerintah menjalankan kewenangannya dalam pengaturan, pengawasan dan pengendalian pengelolaan sumber daya air secara keseluruhan.

Isin pengusahaan antara lain memuat substansi alokasi air dan /atau ruas (bagian) sumber air yang diusahakan.

\section{Pasal 45 ayat 2}

Pengusahaan sumber daya air permukaan yang meliputi satu wilayah sungai (cetak tebal dari penulis) hanya dapat dilaksanakan oleh badan usaha milik negara atau badan usaha milik daerah di bidang pengolaan sumber daya air atau kerja sama antara badan usaha milik negara dengan badan usaha milik daerah.

\section{Pasal 45 ayat 4}

Pengusahaan sebagaimana dimaksud pada ayat (3) dapat berbentuk: a. Penggunaan air pada suatu lokasi tertentu sesuai persyaratan yang ditentukan dalam perizinan.

b. Pemanfaatan wadah air pada suatu lokasi tertentu sesuai persyartan yang ditentukan dalam perizinan; dan/atau

c. Pemanfaatan daya air pada suatu lokasi tertentu sesuai persyaratan yang ditentukan dalam perizinan.

Hak-hak badan swasta yang terlibat sangat terlindungi dalam undang-undang ini. Sekali hak akan alokasi air diperoleh oleh badan usaha swasta maka jika terjadi situasi yang mendesak misalnya hak alokasi. diambil kembali oleh pemerintah atau pemerintah daerah melalui perubahan urutan prioritas, maka badan usaha swasta tersebut akan memperoleh kompensasi. Lihat pasal 29 ayat 3,4 dan 5 . kompensasi tidak diperlukan jika tidak ada motivasi melindungi sektor swasta, karena untuk keperluan sehari-hari dan irigasi rakyat sudah dinyatakan sebagai prioritas utama.

\section{Pasal 29 ayat 5}

Apabila penetapan urutan prioritas penyediaan sumber daya air sebagaimana dimaksud pada ayat (4) menimbulkan kerugian bagi pemakai sumber daya air, pemerintah atau pemerintah daerah wajiban mengatur kompensasi kepada pemakainya.

\section{Pasal 29 ayat 4}

Urutan prioritas penyediaan sumber daya air selain sebagaimana dimaksud pada ayat (3) ditetapkan pada setiap wilayah sungai oleh pemerintah atau pemerintah daerah sesuai dengan kewenangannya.

\section{Pasal 29 ayat 3}

Penyediaan air untuk memenuhi kebutuhan pokok sehari-hari dan irigasi bagi 
pertanian rakyat dalam sistem irigasi yang sudah ada merupakan prioritas utama penyediaan sumber daya air di atas semua kebutuhan.

Hak yang sudah diperoleh kuat sekali kedudukannya melalui hak guna usaha yang diberikan kepada badan usaha swasta yang dimaksud. Lihat pasal 9 ayat 1 .

\section{Pasal 9 ayat 1}

Hak guna usaha air dapat diberikan kepada perseorangan atau badan usaha dengan izin dari pemerintah atau pemerintah daerah sesuai dengan kewenangannya.

Badan usaha swasta sangat dimungkinkan untuk mendapatkan alokasi air dan hak guna usaha karena sejak dari penyusunan pola pengelolaan sumber daya air, dunia usaha akan dilibatkan seluasluasnya. Lihat Pasal 11 ayat 3.

\section{Pasal 11 ayat 3}

Penyusunan pola pengelolaan sumber daya air sebagaimana dimaksud pada ayat (2) dilakukan dengan melibatkan peran masyarakat dan dunia usaha seluasluasnya.

Kepentingan badan usaha swasta bisa menjadi sangat kuat jika pemerintah berkolaborasi dengan badan usaha swasta dan tidak berpihak pada masyarakat banyak, yang secara toeritis tidak mungkin namun secara praktis sudah sering kali terjadi di Indonesia. Pernyataan ini didukung fakta bahwa wadah koordinasi yang berbentuk Dewan Sumber Daya Air, anggotanya seimbang antara pemerintah dan non pemerintah. Sementara anggota non pemerintah terbagi menjadi kelompok pengguna dan pengusaha sumber daya air. Lihat pasal 86 ayat 3 beserta penjelasannya.

\section{Pasal 86 ayat 3}

Wadah koordinasi sebagaimana dimaksud pada ayat (1) beranggotakan unsur pemerintah dan unsur non pemerintah dalam jumlah yang seimbang atas dasar prinsip keterwakilan.

\section{Penjelasan pasal 86 ayat 3}

Yang dimaksud dengan prinsip keterwakilan adalah terwakilinya kepentingan unsur-unsur yang terkait, misalnya sektor, wilayah, serta kelompok pengguna dan pengusaha sumber daya air. Kelompok pakar, asosiasi profesi, organisasi masyarakat dapat dilibatkan sebagai nara sumber.

Yang dimaksud dengan seimbang adalah jumlah anggota yang proporsional antara unsur pemerintah dan unsur non pemerintah.

\section{Studi Literatur Dampak Privatisasi}

Seperti diungkapkan di depan, privatisasi sumber daya air tidak selalu berarti komersialisasi atau komodifikasi (karena kedua istilah ini hampir sama maknanya, selanjutnya istilah yang akan dipergunakan adalah komersialisasi).

Meskipun bisa diperdebatkan: komersialisasi dalam makalah ini akan diartikan bahwa regulasi dari pemerintah sangat minimal. Penerapan water market dengan tradable water right-nya merupakan contoh komersialisasi dengan regulasi minimal. Beberapa negara di dunia yang sangat progresif dalam hal ini adalah Chile, ${ }^{14}$

${ }^{14}$ Lihat artikel Carl J. Bauer. 1997. Bringing Water Markets Down to Earth: the Political Economy of Water Rights in Chile, 1976-95 dan artikel Matthew D. Davis. 2004. Indigenous Rights and Modem Water Management in Chile. 
Meksiko, negara bagian Amerika Serikat Barat Daya, Israel dan Spanyol. ${ }^{15}$ Sementara negara yang melakukan privatisasi tetapi ketat dalam regulasi sebagai contohnya adalah Inggris dan Wales. ${ }^{16}$

Penerapan water market dan tradable water rights mengandung implikasi penerapan konsep opportunity cost di dalam pengelolaan sumber daya air. Air akan dijual kepada mereka yang mau dan mampu membayar lebih besar. ${ }^{17}$ Secara teoritik meskipun ada pro dan kontra namun komersialisasi sumber daya air dengan watermarket dan tradable water right-nya diakui oleh beberapa ahli yang pro, termasuk Bank Dunia, mengandung beberapa kelemahan. Kelemahan yang dimaksud adalah bahwa terjadi kegagalan pasar (market failure) dalam penerapan mekanisme pasar untuk sumber daya air untuk mengarahkan pada alokasi yang paling efisien. Kegagalan pasar yang dimaksud adalah akibat dari barang publik, air khususnya untuk irigasi dan air bersih perpipaan perkotaan bersifat natural monopoly, adanya eksternalitas, air termasuk ke dalam kategori merit good, dan fakta bahwa pengelolaan air mengandung transaction cost yang tinggi. ${ }^{18}$

Berikut studi literatur tentang dampak privatisasi dari berbagai artikel jurnal. Kajian tentang dampak komersialisasi tidak akan dilakukan karena Indonesia melalui UU No. 7 tahun 2004 tentang Sumber Daya Air tidak menerapkan konsep ini. ${ }^{19}$

\section{Akses Kelompok Miskin}

Masalah pertama yang bisa diidentifikasi dari beberapa artikel jurnal adalah masalah akses kelompok miskin perkotaan terahdap air bersih yang sudah diprivatisasi. Fakta menunjukkan bahwa kelompok miskin membayar 4 sampai 100 kali lipat ${ }^{20}$ bahkan dalam penelitian Asian Development Bank
(ADB) di Delhi masyarakat miskin harus membayar sampai 489 kali mereka yang

15 Lihat artikel Wim H. Kloezen, 1998. Water Markets between Mexican Water User Associations dalam Ater Policy 1, hal. 438. Perdebatan bagi yang pro dan yang kontra terhadap water market bisa dilihat dalam artikel ini juga. Yang pro lebih banyak bersifat teoritik argumennya, sementara yang kontra berupa penelitian empirik termasuk artikel Kloezen tersebut di atas. Untuk kasus dampak komersialisasi pada air bersih perkotaan silahkan baca artikel Jose esteban Castro. 2004. Urban Water and the Politics of Citizenship: the Case of the Mexico City Metropolitan Area During the 1980s and 1990s.

${ }^{16}$ Lihat artikel David Kinnersley. 1998. Privatized Water Services in England and Wales: A Mixed Verdict after Nearly A Decade dan John W. Sawkins. 1995. Yardstick Competition in the English and Welsh Water Industry.

${ }^{17}$ Penjelasan lengkap tentang hal ini silahkan baca artikel Wijanto Hadipuro. 2003. Kebijakan Bank Dunia tentang Manajemen Air dan penjelasan Wijanto Hadipuro pada artikel Kompas tanggal 14 September 2003 hal. 1 berjudul RUU Sumber Daya Air Harus Ditinjau Ulang.

${ }^{18}$ Lihat dua dokumen Bank Dunia Water Resources Management A World Bank Policy Paper dan artikel Bank Dunia yang disusun oleh Paul Holden dan Mateen Thobani. 1996. Policy Research Working Paper 1627 Tradable Water Rights serta tinjauan kritis Wijanto Hadipuro. 2003. Counter Arguments untuk Privatisasi Sumber Daya Air Melalui Tradable Water Rights.

19 Semula memang dalam beberapa versi awal RUU ini, Indonesia menerapkan konsep tradable water rights: hak guna dapat disewakan dan dipindahtangankan. Namun syukurlah bahwa akhirnya masukan dari Kru HA didengar dan diadopsi. Tidak adanya komersialisasi seperti praktek PDAM menjadi sapi perah bagi PAD juga nampak pada pasal 77 ayat 1 dan 3 . Sumber dana misalnya dari hasil penerimaan biaya jasa pengelolaan sumber daya air (ayat 3 poin c) digunakan semata-mata untuk membiayai pengelolaan yang menjamin keberlangsungan fungsi sumber daya air (ayat 1 dan penjelasannya). ${ }^{20}$ Lihat DFID, 1998: 10 dalam op.cit. Bakker, 2003 b: 336. 
memiliki koneksi pipa. ${ }^{21}$ ADB mengakui bahwa sektor privat memang tidak mau atau tidak bisa memecahkan masalah pelayanan pada daerah miskin, jika pun bisa prestasinya tidak lebih baik dari sektor publik (Bakker). Apalagi sektor privat yang bermotif keuntungan, sektor publik pun enggan untuk memperluas akses ke daerah miskin (Miarsono, 2000 dan Hakim, 2000).

Privatisasi sektor swasta dalam penyediaan air bersih punya karakteristik monopolistik, sehingga secara teoritik maupun praktis tidak mungkin sektor swasta secara suka rela menyediakan air bersih pada masyarakat miskin yang kemampuan membayarnya rendah (Hardoy dan Schusterman, 2000). 'Kealpaan' negosiasi kontrak antara pemerintah dengan perusahaan swasta seperti yang terjadi di Argentina tidak mendorong Aquas Argentinas, perusahaan swasta pemegang koneksi di Buenos Aires ${ }^{22}$ karena penyediaan air bersih ke pemukiman miskin di Argentina berarti tambahan biaya maintainance bagi aquas Argentinas (Hardoy dan Schusterman, 2000). Disinsentif seperti ini terbukti terjadi di Jakarta (bakker) dan juga di Buenos Aires (Hardoy dan Schusterman, 2000).

Perusahaan swasta cenderung secara strategis melakukan cherry picking, area yang menjanjikan keuntungan akan diambil oleh perusahaan swasta ${ }^{23}$ dan area yang tidak menghasilkan keuntungan akan tetapi ditinggalkan untuk dikelola oleh sektor publik dengan subsidinya. Meskipun ada dalam kontrak, sangat jarang ada perusahaan swasta yang mampu memenuhi obligasi kontrak ini (Swyngedouw, 2003 dan Castro, 2004), kecuali jika ada insentif yang cukup besar seperti dalam bentuk pembayaran kompensasi, pemberian subsidi dari pemerintah, pengurangan atau pembebasan pajak (Hardoy dan Schusterman, 2000).

Kasus keengganan perusahaan swasta melayani daerah miskin terbukti dalam kasus Mexico City Metropolitan Area. ${ }^{24}$ Meskipun rata-rata konsumsi per kapita per hari naik sampai 300 liter per kapita per hari setelah dilakukan komesialisasi di Meksiko namun kenyataannya konsumsi di daerah termiskin di Mexico City Metropolitan Area hanya 4 liter per kapita per hari (Lascurain, 1995 dalam Castro, 2004).

Salah satu penyebab kegagalan pelayanan pada daerah miskin adalah kenyataan bahwa pelibatan sektor swasta membuat negara dan civil society apalagi masyarakat biasa tidak mampu mencek kegiatan detil operasi operator swasta (Castro, 2004). Domain publik telah berubah menjadi milik korporasi swasta.

Perusahaan swasta berharap bahwa penyediaan air bersih untuk masyarakat

${ }^{21}$ Lihat Second Water Utilities Data Book Asian and Pacific Region, Asian Developments Bank Oktober 1997 Tabel 11 dan 18.

${ }^{22}$ Suez sebagai pemegang hak konsesi melalui anak perusahaannya Aquas Argentinas selama 30 tahun di Buenos Aires Argentina ini akhirnya pada bulan Juli 2002 memutuskan kontrak kerja (lihat artikel Sara Grusky. 2003. Water Privatization Fiascos: Broken Promises and Social Turmoil).

${ }^{23}$ Perusahaan swasta PT Sarana Tirta Ungaran lebih memilih menyediakan air untuk industri yang standar kualitasnya rendah namun tarifnya Jebih tinggi sementara untuk masyarakat dilakukan oleh PDAM Kabupaten Semarang. Lihat Kerangka Acuan kajian Dampak Lingkungan (KA ANDAL) PT Tirta Ungaran 2003, Lampiran 2 hal. 1.

${ }^{24}$ Air bersih di kota Meksiko ditangani oleh Suez melalui kontrak manajemen (management support). Lihat htttp://www.suez.com/ documents/english/gestion-uk.pdf di-download tanggal 3 Januari 2003. 
miskin akan dilakukan oleh berbagai aktor. Masyarakat miskin berpartisipasi melalui penyediaan tenaga kerja, sumber dana disediakan oleh pemerintah, dan penyiapan kapasitas masyarakat miskin untuk berpartisipasi dilakukan oleh Lembaga Swadaya Masyarakat (LSM) sementara perusahaan swasta dalam hal ini Aquas Argentinas menyiapkan kapasitas teknis, sumber dana dan perlengkapan (Hardoy dan Schusterman, 2000). Bahkan menurut Pirez (2002) dalam kasus Buenos Aires, penduduk miskin dipaksa untuk melakukan usaha self help untuk sebagian infrastruktur yang kemudian dialihkan kepada Aquas Argentinas.

\section{Kontrol Tarif}

Masalah kedua adalah masalah kontrol pemerintah terhadap penetapan tarif sektor privat yang berakibat khususnya pada kelompok miskin perkotaan dan pada masyarakat secara keseluruhan. Sebagai contohnya, setelah privatisasi di Inggris tahun 1989, tarif air naik secara signifikan dan banyak konsumen yang tidak membayar diputus koneksinya (Swyngedouw, 2003).

Fakta bahwa rata-rata tarif air yang disediakan oleh pihak swasta cenderung lebih tinggi dibandingkan perusahaan publik atau kemitraan antara publik dan privat ${ }^{25}$ menunjukkan bahwa kontrol terhadap penetapan tarif merupakan hal yang krusial dalam pelibatan sektor swasta dalam pengelolaan air bersih perkotaan. Sebagai contoh jika saat konsesi diberikan Aquas Argentinas menjanjikan penurunan tarif sebesar $26,9 \%$ kenyataannya malah naik $20 \%$. (Loftus dan McDonald, 2001).

Dalam kasus privatisasi di Inggris dan Wales, Office of Water Services (OFWAT) didirikan khusus dengan tugas untuk melakukan regulasi ekonomi bagi industri air. Regulasi ekonomi yang dimaksud adalah penentuan batas atas harga melalui comparative atau yardstick competition (Sawkins, 1995 dan Bakker, 2003a: 362). Hal ini dimaksudkan untuk mencegah manajemen perusahaan swasta dengan monopoli alamiahnya akan mempergunakan kekuatan pasarnya dengan cara menentukan harga yang tinggi dan mengurangi kualitas dalam jangka panjang.

\section{Penelitian Sawkins}

(1995) menunjukkan bahwa yardstick competition bekerja dengan baik, meskipun tidak mudah pada awalnya karena penentuan faktor pengali harga untuk penyesuaian periode lima tahunan masih terlalu tinggi. Namun fakta menunjukkan bahwa laba yang diperoleh perusahaan air di Inggris dan Wales yang diharapkan berdasarkan perhitungan $7 \%$ kenyataannya tidak pernah di bawah $10 \%{ }^{26}$ (Miller-Bakewell, 1998 dalam Bakker 2003a). Di Buenos Aires bahkan profit Aquas Argentinas tahun 1995 - 1997 mencapai $28,9 \%, 25,4 \%$ dan $21,4 \%$ (Loftus dan McDonald, 2001).

\section{Cherry Picking}

Seperti dikemukakan di depan, perusahaan swasta cenderung melakukan cherry picking termasuk di dalamnya dalam hal strategi pemodalan untuk investasi. Tahun 2000 salah satu perusahaan air di Inggris Kelda mengajukan usulan untuk menjual perusahaan pemasok air bersihnya Yorkshire Water kepada konsumennya. Konsumen akan memiliki seluruh aset, sementaraYorkshire Water masih tetap akan

${ }^{25}$ Lihat artikel David Hall. 2001. Water in Public Hands, hal. 11.

${ }^{26}$ Menurut op.cit Loftus dan McDOnald. 2001: 192 rata-rata laba 9,3\% untuk tahun 1999-2000 dan 9,6\% untuk tahun sebelumnya. 
melaksanakan operasi dan pemeliharaan. Sebuah proses yang disebut mutualisasi, setelah 10 tahunan proses privatisasi. Tujuan mutualisasi adalah untuk memperoleh pembiayaan yang lebih murah (Bakker, 2003a).

Di Inggris sedang berkembang model associative self-governance, atau apa yang disebut juga dengan mutualisasi, dimana idenya adalah memberikan kontrol lebih besar kepada konsumen pada jasa layanan publik seperti kesehatan, pendidikan dan termasuk di dalamnya macam-macam utilitas seperti air dan gas. Model ini berkembang setelah bangkrutnya penyedia infrastruktur kereta api Railtrack.

Dalam kasus air, menariknya adalah ide ini dilakukan setelah perusahaan swasta memperoleh keuntungan yang besar, dan pembagian deviden yang besar dengan dibiayai dari pinjaman (Bakker, 2003a).

Proses mutualisasi terjadi setelah perusahaan swasta kaya uang tunai pada periode setelah privatisasi dan bisnisnya telah jenuh, teregulasi dan prospek keuntungannya menurun di masa yang akan datang (Bakker, 2003a). Apakah proses mutualisasi akan terjadi pada industri air pipa perkotaan di negara lain? Waktu akan membuktikan. Namun jika hal ini benarbenar terjadi dan logikanya akan terjadi lalu untuk apa negara seperti Indonesia mengikuti proses privatisasi yang akan diikuti mutualisasi? Mengapa tidak melompat saja ke proses mutualisasi?

\section{Korupsi}

Masalah keempat adalah masalah korupsi. Swyngedow (2003) menuliskan bahwa kontrak konsesi Thames Water untuk Jakarta harus diulang karena dugaan korupsi. Dugaan korupsi juga terjadi untuk kasus privatisasi di Grenoble, Tallin,
Lesotho, dan Kazakhstan. Enron, Vivendi, dan Suez adalah beberapa pelaku lain yang dituduh melakukan penyuapan pada partai politik demi untuk menjaga kepentingan bisnisnya. Dalam kasus Buenos Aires, Loftus dan McDonald (2001) juga menulis hal yang sama yaitu dugaan korupsi yang kental. Mereka juga menulis-kan bahwa Vivendi, perusahaan air terbesar di dunia, dituduh melakukan korupsi pada paling tidak pada enam kasus dan dugaan serupa untuk kasus Suez di Jakarta.

Sebagai contoh kasus korupsi yang lain adalah kasus pengambilalihan sumur dan pipa infrastruktur milik masyarakat di Mexico City Metropolitan Area oleh pemerintah. Ada dugaan perusahaan swasta pengelola air bersih menyuap walikota untuk mengambil keputusan tersebut agar mereka mampu mengontrol penuh air di daerah tersebut (Castro, 2004).

\section{Degradasi Lingkungan}

Masalah kelima adalah masalah degradasi lingkungan. Meskipun tidak diurai dengan detil, Loftus dan McDonald (2001) menyatakan bahwa konsesi yang diberikan kepada Aquas Argentinas terbukti problematik dalam kaitan dengan degradasi lingkungan. Logikanya memang tidak terlalu sulit. Perusahaan swasta akan lebih cenderung memilih sumber air tanah misalnya yang bisa berakibat pada degradasi lingkungan daripada air permukaan, karena kualitas air tanah lebih baik dan biaya pengolahannya lebih murah. Perusahaan swasta juga enggan untuk melakukan konservasi selama not in my back yard.

\section{Peran Lembaga Multi-lateral}

Melawan arus memang berat, apalagi yang dilawan adalah International Monetary Fund (IMF) dan Bank Dunia beserta bank- 
bank regionalnya. Mengutip British Water, 1998, Bakker (2003b) menyebutkan bahwa di Timur Jauh privatisasi air dilakukan melalui tekanan IMF. Demikian juga dengan privatisasi di Buenos Aires, peran Bank Dunia dan Inter-American Development Bank tidak dapat diabaikan (Loftus dan McDonald, 2001). Peran ADB, IMF dan Bank Dunia juga besar dalam kasus privatisasi air di Thailand (Chantawong), di Manila yang berperan dalam privatisasi air bersih di Kota Manilla adalah Bank Dunia (Perez-Corral, 2003).

\section{Implikasi Kedepan untuk Indonesia}

Melihat masalah-masalah yang ditimbulkan dari privatisasi, Undang-undang No 7 tahun 2004 tentang Sumber Daya Air tidak menunjukkan akan mampu memberikan jaminan bahwa masalah tersebut tidak akan terjadi. Misalnya saja kasus badan regulasi ekonomi (OFWAT) di Inggris tentunya tidak dapat diselesaikan melalui Badan Musyawarah seperti dalam Rancangan Peraturan Pemerintah tentang Pengembangan Sistem Penyediaan Air Minum atau badan yang berada di bawah dan bertanggung jawab kepada menteriyang membidangi sumber daya air. Keanggotaan, independensi badan yang dibentuk, mekanisme kontrol tarif dan perluasan jangkauan layanan pada masyarakat miskin tidak nampak jelas dalam undang-undang tersebut.

Bagaimana mekanisme kontrol harga melalui Yardstick competition yang terbukti tidak mampu mencegah pengambilan keuntungan yang besar bagi perusahaan swasta bisa diterapkan di Indonesia, dengan fakta bahwa Perusahaan Daerah Air Minum (PDAM) yang ada di Indonesia adalah Badan Usaha Milik Daerah yang tentunya masingmasing daerah punya kepentingan yang berbeda-beda; padahal badan usaha swasta akan bekerja sama atau mengambil alih PDAM yang selama inj dimiliki oleh daerah kabupaten atau kota. Saat ini saja saat masih dikelola pemerintah daerah kabupaten atau kota indikasi untuk tidak mematuhi peraturan dari pemerintah pusat sudah terjadi. Sebagai contoh, banyak PDAM yang tidak lagi memperhatikan instruksi Menteri Dalam Negeri No.8 tahun 1998 tentang penetapan tarif.

Tidak jelas juga bagaimana mekanisme konservasi mengingat tidak adanya aturan alokasi dana konservasi antar instansi, antar kabupaten/kota, dan antar propinsi. ${ }^{27}$ Apalagi mekanisme jaminan kaum miskin perkotaan akan mendapat layanan air bersih

${ }^{27}$ Dalam Diskusi Publik Undang-undang Sumber Daya Air: Implikasinya bagi Publik yang diselenggarakan oleh Koalisi Rakyat untuk Hak Atas Air di Jakarta 24 Maret 2005, Benny D. Setianto, salah satu pembicara, menyatakan bahwa ada kelemahan mendasar dalam undang-undang ini khususnya yang berkaitan dengan hak guna. Pasal 7 ayat 2 menyatakan bahwa hak guna tidak bisa disewakan atau dipindahtangankan. Artinya pemerintah sebagai wakil negara juga tidak bisa menyewakan atau memindahtangankan hak guna yang dimilikinya. Padahal pasal 9 ayat 1 menyatakan bahwa hak guna dapat diberikan pada perseorangan atau badan usaha.Implikasinya adalah bahwa perseorangan atau badan usaha tidak menyewa atau memindahtangankan karena dilarang oleh Pasal 7 ayat 2 , sehingga hak guna yang diperoleh oleh perseorangan atau badan usaha sifatnya pinjaman. Konsekuensinya kewajiban yang melekat temasuk di dalamnya kewajiban konservasi masih di tangan negara. Akibatnya seperti menurut pembicara lain dalam diskusi tersebut, Budi Widianarko, badan usaha dan perseorangan hanya wajib ikut serta (artinya kewajiban di tangan negara) melakukan kegiatan konservasi yang diatur dalam Pasal 47 ayat 3 ). 
setelah pelibatan sektor swasta. Demikian juga bagaimana langkah-langkah apa agar kasus korupsi pemberian konsesi di Jakarta kepada dua perusahaan asing yang sangat terkenal di luar negeri tidak akan terjadi lagi. Apakah mekanisme dua kali konsultasi publik bisa menjamin hal tersebut tidak terjadi lagi di masa yang akan datang?

Jika fakta mutualisasi benar, lalu untuk apa Indonesia bersikeras untuk melibatkan badan usaha swasta dalam penyediaan air minum.

Potret buram sektor air perkotaan pada khususnya dan sektor air pada umumnya di Indonesia akan menjadi kenyataan jika Mahkamah Konstitusi menolah usaha judicial review. Undang-undang No 7 tahun 2004 tentang Sumber Daya Air khususnya yang berkaitan dengan pellibatan badan usaha swasta.

\section{Daftar Pustaka}

2005. Keterangan Tertulis Pemerintah atas Permohonan Hak Lji Undang-undang Republik Indonesia No 7 tahun 2004 tentang Sumber Daya Air terhadap undang-undang Dasar Republik Indonesia tahun 1945 tanggal 28 Januari 2005.

2003. Pelurusan Opini Publik terkait dengan RUU Sumber Daya Air yang dipresentasikan oleh Siswoko dalam Diskusi 'Bedah RUU Sumber Daya Air' Indonesian Forum on Globatization dan Harian Kompas Semarang tanggal 7 Oktober 2003.

Undang-undang Republik Indonesia Nomor 7 tahun 2004 tentang Sumber Daya Air.
2003. BUMN (Badan Usaha Milik Negara) Undang-Undang RI No. 19 tahun 2003. Bandung: Fokus Media

Bakker, J. Karen 2003. 'Trickle Down'? The Pro-poor Water Supply Debate and the Case of Jakarta, Indonesia.

Bakker, J. Karen 2003a. From Public to Private to .. Mutual? Restructuring Water Supply Governance in england and Wales Dalam Geoforum 34, hal. 361

Bakker, J. Karen 2003b Archipelagos and Networks: Urbanization and Water Privatization in the South. Dalam The Geographical Journal Vol. 169 No. 4 hal. 328-341

Bank Dunia. 1993. Water Resources Management $A$ World Bank Policy Paper. Washington D.C. : The World Bank.

Basri, Faisal. 2004.Privatisasi. Presentasi dalam Seminar Nasional Privatisasi BUMN dan Implikasinya di Indonesia Program Magister Manajemen UII Yogyakarta.

Bauer, Carl J.. 1997. Bringing Water Markets Down to Earth: the Political Economy of Water Rights in Chile, 1976-95

Castro, Jose esteban. 2004. Urban Water and the Politics of Citizenship: the Case of the Mexico City Metropolitan Area During the 1980s and 1990s.

Chantawong, Montree, Water Privatization in Thailand: Situation and impact. 
Dampak Privatisasi Air Bersih Perkotaan Bagi Masyarakat..;; Wijanto Hadipuro

Davis, Matthew D. 2004. Indigenous Rights and Modern Water Management in Chile.dalam Gerald Shelcke, Donald F. Hayes, dan David K. Stevens (eds) Critical Transitions in Water and Environmental Resources Management. Salt lake City: Prosiding World Water and Environmental Congress.

Direktorat Jenral Tata Perkotaan dan tata Pedesaan Departemn Pekerjaan Umum. Rancangan Peraturan Pemerintah tentang Pengembangan Sistem Penyediaan Air Minum.

Ertuna, C. 1997. Second Water Utilities Data Book Asian and Pasific Region Asian Development Bank.

Gleick, Peter H. (et. al). 2002. The World's Water The Biennial Report on Freshwater Resources 2002-2003. Washington: Island Press.

Grusky, Sarah. 2003. Water Privatization Fiascos: Broken Promises and Social Turmoil). Washington D.C. Public Citizen's

Hadipuro, Wijanto. 2003. Counter Arguments untuk Privatisasi Sumber Daya Air Melalui Tradable Water Rights. Dipresentasikan dalam Diskusi terbatas Menelaah Krisis Air di Indonesia di Pringsewu Garden Restaurant Yogyakarta tanggal 6 September 2003

Hadipurom Wijanto. 2003. Kebijakan Bank Dunia tentang Manajemen Air dipresentasikan di Dikusi Krisis air dan Kebijakan Bank Dunia di Program Magister Lingkungan dan Perkotaan Unika Soegijapranata Semarang tanggal 11 Juli 2003.
Hakim, Janur. 2000. Explaining Water Supply Performance: Patterns of Interorganizational Relationship in Urban Water Supply Delivery. Disertasi Doktor di Universitas Indiana.

Hall, David. 2001. Water in Public Hands. London: Public Services International Research Unit (PSIRU).

Hardoy, Ana dan Ricardo Schusterman, 2000. New Models for the Privatization of Water and Sanitation for the Urban Poor. Dalam Environment \& Unanization vol. 12 No. 2 hal. $63-67$

Holden, Paul dan Mateen Thobani. 1996. Policy Research Working Paper 1627 Tradable Water Rights Washington D.C. The World Bank

Kinnersley, David. 1998. Privatized Water Services in England and Wales: A Mixed Verdict after Nearly A Decade

Kloezen, Wim H.. 1998. Water Markets between Mexican Water User Associations dalam Ater Policy 1, hal 437 -455 .

Kompas, 2003. RUU Sumber Daya Air Harus Ditinjau ulang. Hal 1 tanggal 14 September 2003.

Kyessi. Alphonce G. 2005. Community based Uban Water Management in Fringe Neighbourhoods: The Case of Dar es Salaam, Tanzania dalam Habjtat international vol. 29 Issue 1. hal. $1-25$. 
Loftus, Alexander J. dan David A. McDonald. 2001. of Liguid Dreams: A. Political Ecology of Water Privatization in Bounes Aires. Dalam Environment \& Urbanization. Vol. 13 No. 2

Mairsono, Harry. 2003. The Provision of Public Services in The Developing World a Case Study of Semarang Indonesia.Disertasi Doktor Universitas Wincounsin -Milwauke.

Perez-corrl, Violeta Q. 2003. Teh Failed Water Privatization in Manila. Dalam Truth behind Water Privatization. Japan Center forASustainable Environment and Society.

Pirez, Pedro. 2002. Bounes Aires: Fragementation and Privatization of the Metropolitan City. Dalam Environment \& Urbaniztion Vol 14 No.1

Sarana Tirta Ungaran. 2003. Kerangka Acuan Kajian Dampak Lingkungan (KANDAL). Semarang: PT. Sarana Tirta Ungaran.
Sawkins, John W.. 1995. Yardstick Competition in the English and Welsh Water Industry. Dalam Utility Policy. Vol. 5 No. 1, hal. $27-36$

Setiawan, Bonnie. 2000. Stop WTO. Jakarta. INFID. Hal. 6-7.

Suez Ondeo. Public.Private Parthership in Management of Water Services di Download tanggal 3 Januari 2003 dari http://www.Suez.com/doduments/ english/gestion-uk.pdf

Swyngedouw, Erik. 2003. Privatising $\mathrm{H} 2 \mathrm{O}$ Turning Local Water into Global Money. Journal fur Entwicklungspolitik. Vol. XIX, hal. 10 $-33$

Yayasan Geni, gita Pertiwi, Program Magister Lingkungan dan Perkotaan Unika Soegijapranata, dan INFID. 2004. Kinerja PDAM di Jawa Tengah - Studi Kritis Antisipasi Privatisasi. 